\title{
Synthesis and Antiproliferative Properties of a New Ceramide Analog of Varacin
}

Adaickapillai Mahendran,,$^{\dagger}$ Ashwini A. Ghogare ${ }^{\dagger}$ Robert Bittman ${ }^{\ddagger}$ Gilbert Arthur ${ }^{\S}$ and Alexander Greer ${ }^{*} \dagger$

${ }^{\dagger}$ Department of Chemistry and Graduate Center, Brooklyn College of the City University of New York, Brooklyn, New York 11210, USA

${ }^{\ddagger}$ Department of Chemistry and Biochemistry, and Graduate Center, Queens College of the City University of New York, Flushing, New York 11367, USA

${ }^{\S}$ Department of Biochemistry and Medical Genetics, University of Manitoba, Winnipeg, Manitoba, Canada R3E 0W3

Corresponding author:

Alexander Greer

Department of Chemistry and Graduate Center

Brooklyn College of the City University of New York

2900 Bedford Avenue

Brooklyn, New York 11210, USA

Phone: 718-951-5000 ext 2830

FAX: 718-951-4607

E-mail: agreer@brooklyn.cuny.edu

Keywords: ceramide drug conjugate, pentathiepin toxicity, polysulfur ring, reactive sulfur species 


\begin{abstract}
A benzopentasulfane was synthesized in 8 steps with a ceramide attached through an amide bond to the 7-position of the heterocycle structure. The anticancer activity of this synthetic ceramidebenzopolysulfane drug conjugate was analyzed against five human cancer cell lines MDA-MB231 (breast), DU145 (prostate), MIA PaCa-2 (pancreas), HeLa (cervix), and U251 (glioblastoma). The ceramide-benzopolysulfane conjugate had $\mathrm{IC}_{50}$ values ranging from 10 to $>20 \mu \mathrm{M}$ with complete cell killing at $12.5 \mu \mathrm{M}$ for MDA-MB-231and $20 \mu \mathrm{M}$ for DU145 and HeLa cells. The ceramide-benzopolysulfane conjugate had $\mathrm{IC}_{50}$ values 1.8 and 4.0 times lower than a PEG benzopolysulfane, $N$-(2-(2-(2-methoxyethoxy)ethoxy)ethyl)benzo[f][1,2,3,4,5]pentathiepine-7-carboxamide, for MDA-MB-231 and DU145 cells, respectively. The parent "unsubstituted" benzopolysulfane, $o-\mathrm{C}_{6} \mathrm{H}_{4} \mathrm{~S}_{5}$, had $\mathrm{IC}_{50}$ values 4.2 times lower and 2.7 times higher than the ceramide benzopolysulfane for MDA-MB-231and DU145 cells, respectively. The results indicate that the polysulfur linkage is needed for activity since benzenedithiol, $o$ $\mathrm{C}_{6} \mathrm{H}_{4}(\mathrm{SH})_{2}$, had $\mathrm{IC}_{50}$ values greater than $30 \mu \mathrm{M}$ with little effect on MDA-MB-231 and DU145 cells. Thus, to account for the bioactivity, a bimolecular reaction of cellular thiol with the ceramide benzopolysulfane is a proposed followed by thiozone $\left(\mathrm{S}_{3}\right)$ extrusion.
\end{abstract}

\title{
1. Introduction
}

This manuscript describes a synthetic approach to ceramide-benzopolysulfane drug conjugate 1 as a new anticancer compound (Scheme 1). Benzopolysulfanes are a unique class of compounds, some isolated from marine tunicates or their associated microorganisms, e.g, varacin (2), lissoclinotoxin A (3), and N,N-dimethyl-5-(methylthio)varacin (4) (Davidson et al., 1991; Litaudon and Guyot, 1991; Compagnone et al. 1994; Searle and Molinski, 1994; Makarieva et 
al., 1995; Liu et al. 2004a; Liu et al. 2004b; Bentley, 2005; Tachibana et al. 2005; Jiang et al., 2012). Common to these natural polysulfane structures is a dopamine core (Ford et al., 1994; Toste and Still, 1995; Molinski, 2004), although synthetic analogs have been prepared (Konstantinova et al. 2004; Konstantinova et al., 2012; Okuma et al., 2012; Zubair et al., 2013; Koyioni et al. 2014).

Benzopolysulfanes have been reported to possess antiproliferative activity with $\mathrm{IC}_{50}$ values in the low micromolar range; for example, ethylaminobenzopentathiepin yielded an $\mathrm{IC}_{50}$ value of $0.26 \mu \mathrm{g} / \mathrm{mL}$ against HeLa cells (Sato et al., 1995). It has been suggested that the bioactivity of varacin 2 derives from DNA damage because of an observed difference in toxicity toward the $\mathrm{CHO}$ cell line EM9 (chlorodeoxyuridine sensitive) compared to BR1 (Davidson et al., 1991). While benzopolysulfanes show promising bioactivity, they remain relatively understudied as therapeutic agents due to the lability of the polysulfur ring and their low water solubility.

To ameliorate the low water solubility problem, in 2010, Bittman et al. synthesized benzopolysulfanes 4- $\mathrm{CH}_{3}\left(\mathrm{OCH}_{2} \mathrm{CH}_{2}\right)_{3} \mathrm{NHC}(\mathrm{O})-\mathrm{C}_{6} \mathrm{H}_{4}-1,2-\mathrm{S}_{\mathrm{x}}(\mathrm{x}=3-7$ and 9) with a PEG group attached through an amide bond, where the pentasulfane 7 was the major constituent (Mahendran et al., 2010). Antiproliferative activity of the PEGylated benzopolysulfanes in cancer cells increased in comparison to the parent-unsubstituted benzopolysulfane (6) due to the PEG substitution. Somewhat relatedly, Bittman reported on a ceramide-disulfane conjugate $N-\left(4^{\prime}, 5^{\prime}-\right.$ dithiaheptanoyl)- $D$-erythro-ceramide that had greater antiproliferative activity than ceramide itself in BT549, A549, and DU145 cancer cells (Bittman et al., 2007). Because sphingolipid ceramides (Delgado et al., 2012; Delgado et al., 2013) are known to play a role in antiproliferative activity (Flowers et al., 2012) as well as cell signaling pathways, e.g., apoptosis, 
cell proliferation and angiogenesis (Gangoiti et al., 2010; Merrill, 2011), we sought to design and test a new ceramide-polysulfane compound, $\mathbf{1}$.

Here, we describe our efforts to (i) synthesize ceramide-benzopolysulfane drug conjugate 1, (ii) identify the number of sulfur linked atoms in the major cyclic product, (iii) examine the anticancer activity of $\mathbf{1}$ compared to 1,2-benzenediothiol $\mathbf{5}$ and benzopolysulfanes $\mathbf{6}$ and $\mathbf{7}$, and (iv) propose a mechanism for its bioactivity. As we will see, the pentasulfur linkage is the key moiety found in ceramide conjugate 1, while other forms may exist, e.g., tri- and heptasulfanes, as will be discussed.

\section{Scheme 1}

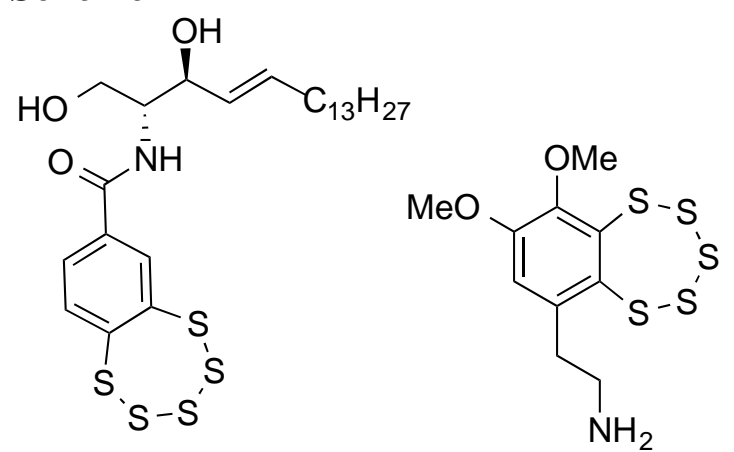

1<smiles>Sc1ccccc1S</smiles>

5
2<smiles>c1ccc2c(c1)SSSSS2</smiles>

6<smiles>COc1c(O)cc(CCN)c2c1SSSSS2</smiles>

3

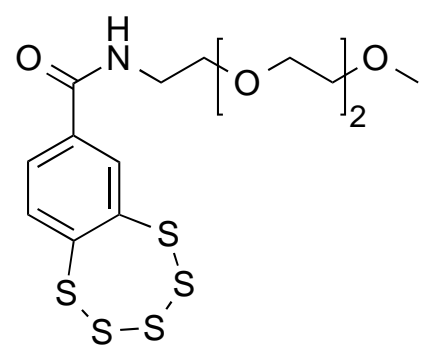<smiles>CNCCc1c(OC)c(OC)c(OC)c2c1SSSSS2</smiles>

4 


\section{Results and Discussion}

2.1. Synthesis. The synthesis of 4-nitrophenyl benzo[f][1,2,3,4,5]pentathiepine-7carboxylate 9 was carried out as described before (Mahendran et al., 2010), using 3,4dihydroxybenzoic acid (8) as a starting material, as well as the use of thiostannole and disulfur dichloride chemistry (Lienard et al 2007; Ogawa et al., 1994; Konstantinova and Rakitin, 2014) (Scheme 2). Briefly, compound 9 was synthesized in seven steps in $2.8 \%$ yield, and was reacted with $D$-erythro-sphingosine $(0.035 \mathrm{mmol})$ in THF to form conjugate $\mathbf{1}$. THF was evaporated leaving a residue of $\mathbf{1}$, which was diluted with $\mathrm{CH}_{2} \mathrm{Cl}_{2}$ and washed with saturated aqueous $\mathrm{NaHCO}_{3}$, then $1 \mathrm{M} \mathrm{HCl}$, and then water, and purified by chromatography on silica. The yield of the reaction to form 1 from 9 was $21 \%$. Our ${ }^{1} \mathrm{H}$ NMR and ${ }^{13} \mathrm{C}$ NMR spectra provide evidence that the amine group in $D$-erythro-sphingosine $(0.035 \mathrm{mmol})$ forms an amide to couple to the 7 position of the heterocycle structure (Figures S1 and S2, Supporting Information). In the ${ }^{13} \mathrm{C}$ NMR spectrum, the quaternary peaks are weak and carbonyl peak at $161.2 \mathrm{ppm}$ is barely visible due to low concentration of the sample. It is possible that other cyclic polysulfanes related to benzopentasulfane 1 were formed in low yields, but this was not determined.

\section{Scheme 2. Synthesis of Ceramide-benzopolysulfane Drug Conjugate 1}<smiles>O=C(O)c1ccc(O)c(O)c1</smiles>

8

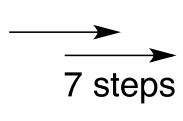

steps

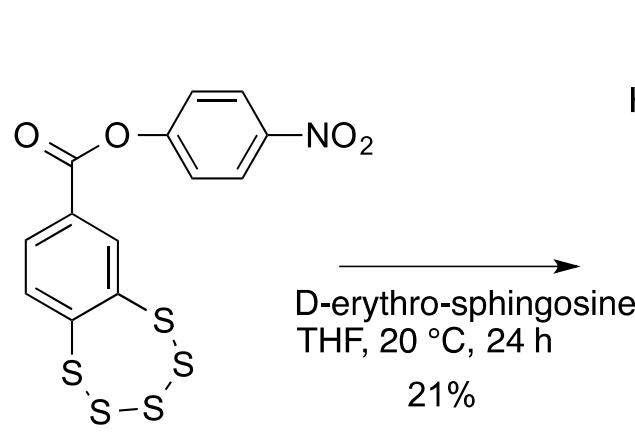

9

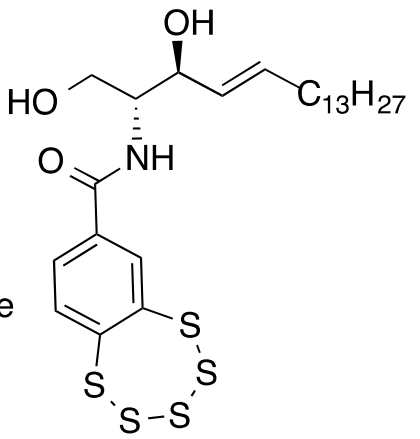

1 
2.2. Mass Spectrometry. In addition to NMR, mass spectrometry was used to assist in the characterization of $\mathbf{1}$ as a pentasulfane. Mass spectrometry has been useful for determining the number of sulfur atoms in polysulfanes (Block et al., 2010; Block, 2013). High-resolution mass spectroscopy data indicated that the number of sulfur present in the polysulfur ring is five. Mass spectrometry data were obtained in electron spray ionization (ESI) method in both positive and negative modes. Positive and negative adducts of the molecule found within a 2-ppm error limit. Calculated mass $\mathrm{m} / z$, for $\mathrm{C}_{25} \mathrm{H}_{39} \mathrm{NO}_{3} \mathrm{~S}_{5}(\mathrm{M})$ is 561.1533 and found 561.1536. In ESI positive mode, the calculated $\mathrm{m} / \mathrm{z}$ mass for $[\mathrm{M}+\mathrm{H}]^{+}$adduct is 562.16063 found 562.16198 , calculated $\mathrm{m} / \mathrm{z}$ mass for $[\mathrm{M}+\mathrm{Na}]^{+}$adduct is 584.14257 and found 584.14247. In negative mode calculated $\mathrm{m} / \mathrm{z}$ mass for $[\mathrm{M}-\mathrm{H}]^{\mathrm{A}}$ adduct is 560.14607 and found 560.14594 , calculated $\mathrm{m} / \mathrm{z}$ mass for $[\mathrm{M}+\mathrm{Cl}]^{-}$adduct is 596.12275 found 596.12254 , calculated $\mathrm{m} / \mathrm{z}$ mass for $\left[\mathrm{M}+\mathrm{CF}_{3} \mathrm{CO}_{2}\right]^{-}$adduct is 674.13894 found 674.13890 .

2.3. Antiproliferative Activity in a New Polysulfane. Figure 1 and Table 1 show the antiproliferative effects of the ceramide-benzopolysulfane conjugate 1 with MDA-MB-231 (breast), DU145 (prostate), MIA PaCa-2 (pancreas), HeLa (cervix), and U251 (glioblastoma) cancer cells.

Cells were incubated with 1 in varying concentrations $(0-20 \mu \mathrm{M})$ for 48 to $72 \mathrm{~h}$ followed by determination of cell viability using MTT assay and cell proliferation with a CyQuant assay (Bittman et al., 2007). Figure 1 shows that compound 1 inhibited the proliferation of all the cell lines with the exception of the glioblastoma U251 cell line. At the highest concentration tested, $20 \mu \mathrm{M}$, proliferation of $\mathrm{U} 251$ cells was inhibited by only $20 \%$ relative to controls incubated with the vehicle. The MDA-MB-231 breast cancer cell line, which is negative for estrogen receptors, progesterone receptors and HER-2 receptors (triple negative) was the most sensitive to 
compound 1, with an $\mathrm{IC}_{50}$ of $10 \mu \mathrm{M}$ and complete loss of proliferation at a concentration of 12.5 $\mu \mathrm{M}$. Triple negative breast tumors do not respond to hormonal therapy or herceptin. Furthermore, $\mathrm{IC}_{50}$ values of 12 and $16 \mu \mathrm{M}$ were obtained with DU145 and MIA PaCa-2 cells, respectively. However, up to $15 \mu \mathrm{M}$, compound $\mathbf{1}$ had little effect on the proliferation of HeLa cells, but a concentration of $20 \mu \mathrm{M}$ resulted in complete loss of proliferation. This may indicate the existence of a threshold in the cellular levels of the compound beyond which rapid loss of proliferative ability of the cells occurs.

Our data on 1 were compared to literature data on antiproliferative effects of 1,2 benzenediothiol 5, benzopolysulfanes $\mathbf{6}$ and 7 against DU145 and MDA-MB-231 cells (Mahendran et al., 2010). The comparisons are shown in Figure 2 for DU145 cells and in Figure 3 for MDA-MB-231 cells. Benzenedithiol 5 had very little effect on the growth of both cell lines and $\mathrm{IC}_{50}$ values were greater than $30 \mu \mathrm{M}$. The ceramide conjugate $\mathbf{1}$ was more active than the parent unsubstituted benzopolysulfane 6 against MDA-MB-231 (breast cancer) cells with an $\mathrm{IC}_{50}$ of $10 \mu \mathrm{M}$ compared with $27 \mu \mathrm{M}$. On the other hand, the ceramide conjugate $1\left(\mathrm{IC}_{50}\right.$ of $\left.12 \mu \mathrm{M}\right)$ was less active than the parent benzopolysulfane $6\left(\mathrm{IC}_{50}\right.$ of $\left.4.9 \mu \mathrm{M}\right)$ in DU145 (prostate cancer) cells. The reason for this difference is unclear as solubility issues would be expected to impact both cell lines similarly.

The ceramide conjugate $\mathbf{1}$ and PEG conjugate $\mathbf{7}$ were able to completely inhibit the proliferation of both the DU145 and MDA-MB-231 cell lines. $\mathrm{IC}_{50}$ values show that PEG conjugate is more effective than the ceramide conjugate. Thus, the ceramide substituent on benzopolysulfane plays a role in enhanced activity in some cells, but not others. The hydrophilicity conferred by the PEG conjugate may be contrasted with the lipophilicity of the ceramide conjugate, where both can influence the localization of the polysulfanes in the cells. 
To estimate lipophilicity, we have computed $(C)$ the octanol-water partition coefficients ( $\log \mathrm{P})$ for the ceramide 1 and PEG 7 drug conjugates using ChemBioDraw (version 14.0). As would be expected, $\mathbf{1}$ is more lipophilic $(C \log \mathrm{P}=9.3)$ than $\mathbf{7}(C \log \mathrm{P}=3.8)$. The effects of $\mathbf{1}, \mathbf{6}-\mathbf{7}$ on human normal epithelial cells were not investigated and therefore no conclusions can be made regarding their in vitro selectivity. Any future clinical utility of the compounds will depend on their ability to be effective against cancer cells at concentrations that are not toxic to normal cells in the body. This will require determination of maximum tolerable levels of the compounds in an animal model in future studies, and its subsequent utilization in efficacy studies in a cancer xenograft model. 


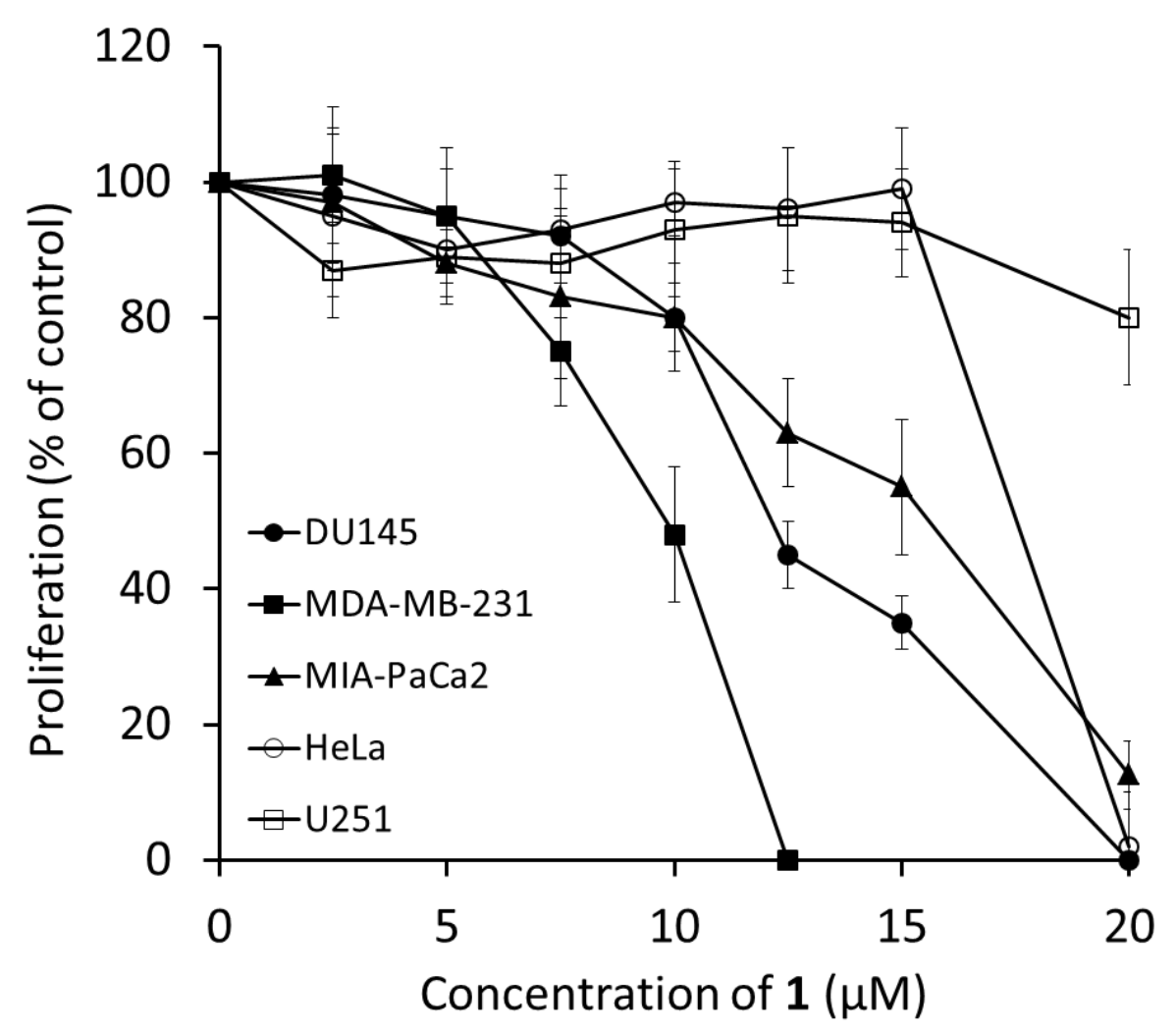

Figure 1. Effect of the ceramide-benzopolysulfane conjugate 1 on the growth of DU145 (•),

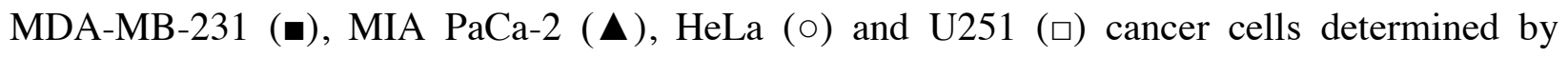
CyQuant and MTT assay as described in the Experimental Section. The values were expressed as the decrease in cell numbers relative to controls without any compound. Data are the mean $\pm \mathrm{SE}$ $(n=6-8)$. 


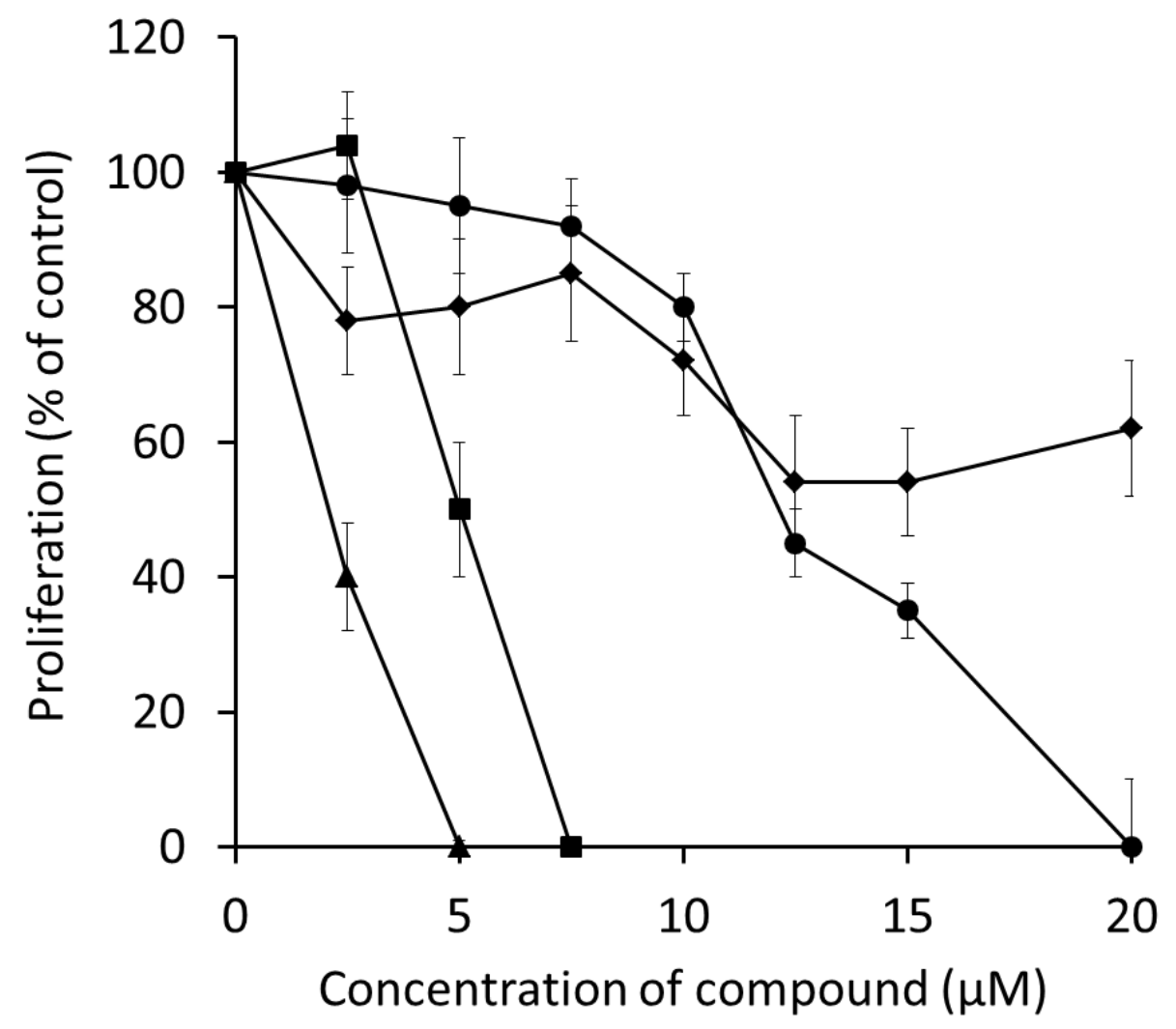

Figure 2. Effect of ceramide-benzopolysulfane conjugate $1(\bullet)$, benzenedithiol $5(\diamond)$,parentbenzopolysulfane 6 ( $\mathbf{\square})$, PEG-benzopolysulfane conjugate 7 ( $\mathbf{\Delta})$ on the growth DU145 (prostate) cancer cells. Data for 5-7 were taken from Mahendran et al., 2010. 


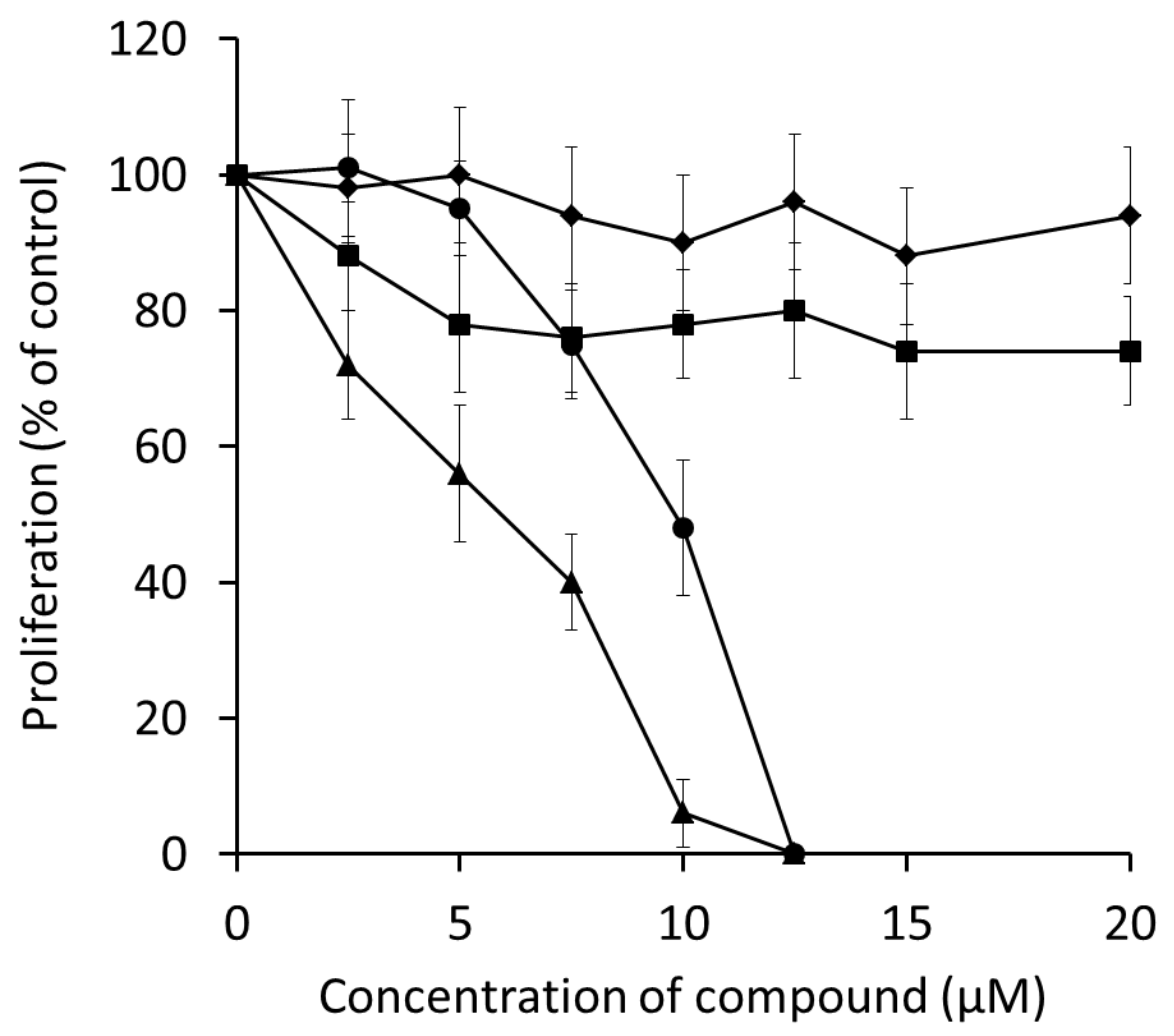

Figure 3. Effect of ceramide-benzopolysulfane conjugate $\mathbf{1}(\bullet)$, benzenedithiol $5(\bullet)$, parentbenzopolysulfane $6(\boldsymbol{\square})$, PEG-benzopolysulfane conjugate 7 (4) on the growth of MDA-MB231 (breast) cancer cells. Data for 5-7 were taken from Mahendran et al., 2010. 
Table 1. $\mathrm{IC}_{50}$ of the Sulfur Compounds Against Cancer Cells (in $\mu \mathrm{M}$ )

ceramide-

cell line benzopolysulfane benzene parent- PEG-benzopolysulfane dithiol $5^{a}$ benzopolysulfane $6^{a} \quad$ conjugate $7^{a}$

conjugate 1

\begin{tabular}{ccccc}
\hline MDA-MB-231 & $10(12.5)^{b}$ & $>30$ & 27 & 5.5 \\
DU145 & $12(20)^{b}$ & $>30$ & 4.9 & 3 \\
MIA PaCa-2 & $16(>20)^{b}$ & - & - & - \\
HeLa & $18(20)^{b}$ & - & - & - \\
U251 & $>20$ & - & - & - \\
${ }^{a}{ }^{b} C_{50}$ values from Mahendran et al., 2010. & \\
${ }^{b}$ Concentrations that resulted in 100\% cell kill are shown in parentheses.
\end{tabular}

2.4. Mechanistic Evaluation. Here, we postulate on the factors underlying the bioactivity of benzopolysulfanes $\mathbf{1 ,} 6$ and 7 (Scheme 3). Two mechanistic aspects were considered. One emanates from polysulfane linkage $\mathrm{RSS}_{\mathrm{x}} \mathrm{SR}$ equilibria, and the second from nucleophilic substitution reactions.

First, a facet of polysulfanes is that even after purification, mixtures of polysulfanes can arise in solution (Schroll and Barany, 1986; Compagnone et al., 1994). Dimers can also arise such as tetrathiocins (Liu, et al., 2004; Liu et al., 2004; Asquith et al., 2015). A facile equilibration has been reported to take place between the tri-, penta-, and heptasulfanes ( $O$ $\mathrm{C}_{6} \mathrm{H}_{4} \mathrm{~S}_{3}, o-\mathrm{C}_{6} \mathrm{H}_{4} \mathrm{~S}_{5}$, and $o-\mathrm{C}_{6} \mathrm{H}_{4} \mathrm{~S}_{7}$ ) (Brzostowska et al., 2007). A previous density functional 
theory (DFT) study showed an alternating stability pattern in benzopolysulfanes where odd membered rings are more stable except the 3-membered ring thiirene (Brzostowska and Greer, 2004). The stability was due to staggered sulfur long-pair electrons in the odd-membered rings, but not in the even-membered rings. Although the smallest even-membered ring (dithiete) was also unstable; it suffers from ring strain (Castillo et al., 2008). The range of the polysulfane linkages is probably solvent dependent, since elemental sulfur is structurally similar to benzopolysulfanes and also tends to equilibrate (Tebbe et al., 1982). What structures are favored in the highest proportions in polysulfane equilibria are probably determined by the amount of available elemental sulfur. As an aside, elemental $S_{8}$ is found in significant amounts in marine environments, which may serve as a source for sulfur in biomolecules (Mopper and Taylor, 1986; Passier et al., 1999), to transform insoluble $\mathrm{S}_{8}$ into a more soluble form in aromatic molecules.

Second, reactions of nucleophiles assist in ring-opening of polysulfanes (Steudel, 2002; Sato, 2002) and may play a role in the bioactivity. Thiols are often present in biological media, and thiolate ions are known nucleophiles for attacking pentathiepin heterocycles (Tonika and Gates, 2003; Chatterji and Gates, 2003). A near neighbor amine group confers an enhanced bioactivity in natural pentathiepins, where trapping studies suggested thiozone, $S_{3}$, as a reactive intermediate (Greer, 2001; Brzostowska and Greer, 2003). For ceramide 1, we suggest that $\mathrm{S}_{3}$ is the reactive intermediate underlying bioactivity. Reactive sulfur species (Sato et al., 1987; Lee et al., 2002; Münchberg et al., 2007; Anwar, 2008; Nielsen et al., 2011; Czepukojc et al., 2013a; Czepukojc et al., 2013b) such as diatomic sulfur, $\mathrm{S}_{2}$, can arise in other polysulfanes (AbuYousef and Harpp, 1998; Abu-Yousef, 2006; Zysman-Colman and Harpp, 2007; Rys et al., 2008; Startsev et al., 2015). Relatedly, the antiproliferative activity of Bittman's ceramide- 
disulfane conjugate, $N$-(4',5'-dithiaheptanoyl)-D-erythro-ceramide, was correlated to a reduction in cellular glutathione (GSH) levels in cancer cells (Bittman et al., 2007). For ceramide 1, the consumption of GSH may be important, as well as the modification of cysteine sites as a cellular thiolstat. Lastly, the benefit of combining ceramide with other drugs, such as tamoxifen, has enhanced the anticancer activity in breast cancer cells (Morad et al., 2012), where further design and anticancer studies of ceramide-polysulfanes would likely prove useful.

\section{Scheme 3}

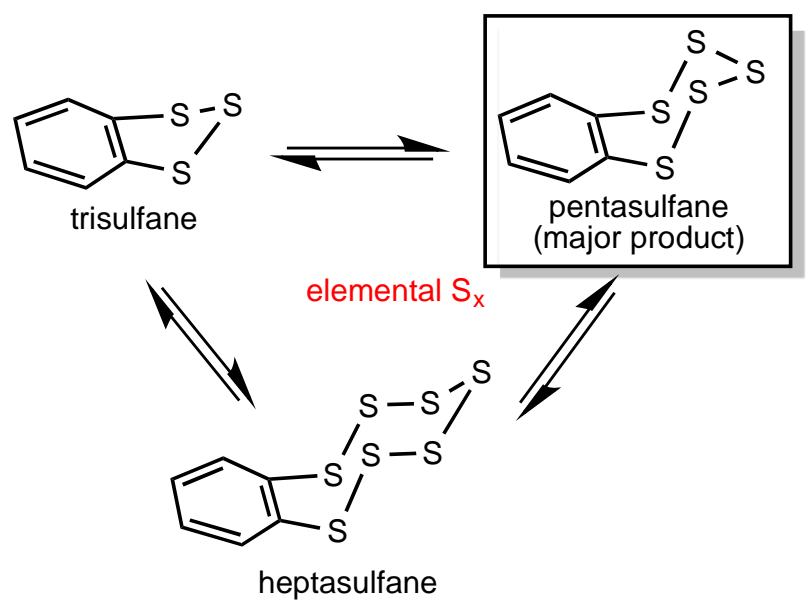

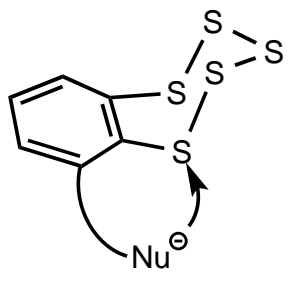

intramolecular

reaction

(neighboring

participation) vs.

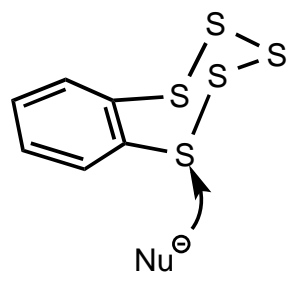

intermolecular reaction (collisional interaction is required) 


\section{Conclusion}

A polysulfane conjugated to a ceramide $\mathbf{1}$ was synthesized and tested for antiproliferative activity in vitro. It was found to have $\mathrm{IC}_{50}$ values ranging from 10 to $12 \mu \mathrm{M}$ for MDA-MB-231 and DU145 cells, and $\geq 16 \mu \mathrm{M}$ for MIA PaCa-2, HeLa and U251 cells. For the bioactivity, intermolecular nucleophilic activation and thiozone $\left(S_{3}\right)$ release are likely key reactions. Unlike natural product polysulfanes with near neighbor amine substituents (e.g., 2-4), ceramide 1 and PEG 7 drug conjugates would require an intermolecular nucleophilic activation. Because key cellular cysteine proteins may be one target of the varacin derivatives, future work could focus on modification of cysteine sites and intramolecular activation control with polysulfane sidegroups other than amines as found in the natural products, $\mathbf{2 - 4}$.

\section{Experimental}

4.1. Chemicals and Reagents. Sodium hydroxide, potassium hydroxide, sodium sulfate (anhydrous), magnesium sulfate (anhydrous), $\mathrm{NaCl}, \mathrm{NaHCO}_{3}, \mathrm{THF}, \mathrm{CHCl}_{3}, \mathrm{CH}_{2} \mathrm{Cl}_{2}$, hydrochloric acid (12 M), acetone- $d_{6}, \mathrm{CDCl}_{3}$, and hexanes were purchased from Sigma-Aldrich USA (St. Louis, MO, USA) or Fisher Scientific USA (Pittsburgh, PA, USA) and used as received without further purification. $D$-erythro-sphingosine was obtained from Avanti Polar Lipids (Alabaster, AL). Compound 9 was synthesized as described in our previous paper (Mahendran et al., 2010). Purification of the product mixtures was carried out by column chromatography using silica gel with particle sizes of 40-60 A. TLC was carried out using silica gel 60F 254 TLC-plates (Sigma-Aldrich, St. Louis, MO, USA). Nuclear Magnetic Resonance (NMR) data were acquired using Bruker $400 \mathrm{MHz}$ instrument (Bruker BioSpin Corporation, Billerica, MA, USA). Proton NMR data were acquired at $400 \mathrm{MHz}$ and ${ }^{13} \mathrm{C}$ NMR data were 
acquired at 100.6 MHz. HRMS data were collected using Agilent 6520 Q-TOF mass spectrometer (Agilent Technologies, Santa Clara, CA, USA).

4.2. $N$-Ceramidobenzo-1,2,3,4,5-pentathiepine-7-carboxamide (1). Yield $2 \mathrm{mg}(21 \%)$.

A 1.5 -mL solution of $D$-erythro-sphingosine $(10.48 \mathrm{mg}, 0.035 \mathrm{mmol})$ of THF was added to a solution of 4-nitrophenyl benzo[f][1,2,3,4,5]pentathiepine-7-carboxylate 9 (7 mg, $0.017 \mathrm{mmol})$ in $2.5 \mathrm{~mL}$ of THF. The reaction mixture was stirred under argon atmosphere overnight for $24 \mathrm{~h}$. The solvent was evaporated and the residue was dissolved in $10 \mathrm{~mL}$ of $\mathrm{CH}_{2} \mathrm{Cl}_{2}$. The organic layer was washed with saturated aqueous $\mathrm{NaHCO}_{3}$ solution (3 times, $10 \mathrm{~mL}$ ea.), $1 \mathrm{M} \mathrm{HCl}(3$ times, $10 \mathrm{~mL}$ ea.), and water (3 times, $10 \mathrm{~mL}$ ea.). The organic solvent was evaporated and the crude product was chromatographed $\left(\mathrm{CHCl}_{3} / \mathrm{CH}_{3} \mathrm{OH}, 10: 1\right)$ to yield $2 \mathrm{mg}$ of $9, \mathrm{R}_{\mathrm{f}}=0.57,1 \mathrm{H}$ $\operatorname{NMR}\left(\mathrm{CHCl}_{3}, 400 \mathrm{MHz}\right): \delta 8.25(\mathrm{~d}, J=1.9 \mathrm{~Hz}, 1 \mathrm{H}), 7.92(\mathrm{~d}, J=8.0 \mathrm{~Hz}, 1 \mathrm{H}), 7.76(\mathrm{dd}, J=7.90$, $1.9 \mathrm{~Hz}, 1 \mathrm{H}), 7.00$ (br s, 1H), 5.81 (dd, $J=12.0,9.0 \mathrm{~Hz}, 1 \mathrm{H}), 5.63(\mathrm{~m}, 1 \mathrm{H}), 4.90(\mathrm{~m}, 1 \mathrm{H}), 4.11$ $(\mathrm{m}, 2 \mathrm{H}), 3.65(\mathrm{~m}, 1 \mathrm{H}), 2.45(\mathrm{~m}, 1 \mathrm{H}), 2.08(\mathrm{~m}, 2 \mathrm{H}), 1.27(\mathrm{~m}, 22 \mathrm{H}), 0.88(\mathrm{t}, J=7.2 \mathrm{~Hz}, 3 \mathrm{H}) ; 13 \mathrm{C}$ NMR $\left(\mathrm{CHCl}_{3}, 100 \mathrm{MHz}\right): \delta 161.2,146.5,144.2,136.2,135.3,134.4,128.7,128.6,74.9,62.5$, 54.5, 32.3, 31.9, 29.7-29.1, 22.7, 14.1; HRMS (+ESI) calcd for $\mathrm{C}_{25} \mathrm{H}_{39} \mathrm{NO}_{3} \mathrm{~S}_{5}=561.1533$, found 561.1536, $(\mathrm{M}+\mathrm{H})^{+}$calcd $\mathrm{m} / \mathrm{z}, 562.16063$ found $562.16198,(\mathrm{M}+\mathrm{Na})^{+}$calcd $\mathrm{m} / \mathrm{z} 584.14257$ found 584.14247; HRMS (-ESI) calcd $m / z(\mathrm{M}-\mathrm{H})^{\mathrm{A}}$ calcd m/z 560.14607, found 560.14594, (M+Cl) calcd $m / z$ 596.12275, found 596.12254, $\left(\mathrm{M}+\mathrm{CF}_{3} \mathrm{COO}\right)^{-}$calcd $m / z$ 674.13894, found 674.13890.

4.3. Cell Culture. The cell lines were grown from frozen stocks originally obtained from the American Type Culture Collection (ATCC). The prostate cancer cell line DU145, breast cancer cell line MDA-MB-231, and pancreatic cancer cell line MIA PaCa-2 cells were grown in DMEM media. The brain cancer cell line U251 and cervix cancer cell line HeLa cells were grown in EMEM medium. All the media were supplemented with $10 \%$ fetal bovine serum and 
1\% (5000 I.U./mL) penicillin/streptomycin to make complete "growth media". The cells were maintained in a humidified atmosphere of $5 \% \mathrm{CO}_{2}$ incubator at $37^{\circ} \mathrm{C}$.

4.4. Cell Proliferation and Cytotoxicity Assays. Cell proliferation and cytotoxicity was assessed by cell proliferation assays as previously described (Bittman et al 2007, Mahendran et al., 2010). Cells were seeded in a 96-well plate at 2000 cells/well density (200 $\mu \mathrm{L}$ of the growth medium per well) and maintained in $5 \% \mathrm{CO}_{2}$ incubator at $37{ }^{\circ} \mathrm{C}$ until they were in $\log$ phase growth. After $24 \mathrm{~h}$ incubation, the growth medium was aspirated out and $200 \mu \mathrm{L}$ of growth medium containing the test compounds (0-20 $\mu \mathrm{M}$ concentration) was added to the cells. Cell proliferation assay: After $48 \mathrm{~h}$ incubation at $37{ }^{\circ} \mathrm{C}$, the growth medium containing the test compounds was removed and the plates were maintained at $-80{ }^{\circ} \mathrm{C}$ for $5-7$ days. The plates were thawed to room temperature, appropriate concentration of CyQuant reagent in lysis buffer (200 $\mu \mathrm{L}$ ) was added to each well and fluorescence was measured using plate reader (excitation 485 $\mathrm{nm} /$ emission $535 \mathrm{~nm}$ wavelength) to determine \% cell proliferation. The CyQuant assay measures the DNA content of the cells, which is a measure of cell numbers. The reagent contains a dye that fluoresces strongly upon binding to DNA. Cell toxicity assay: Toxicity of the cells was measured by the MTT assay, which measures the metabolic activity found in viable cells. After $72 \mathrm{~h}$ incubation at $37^{\circ} \mathrm{C}$, the growth medium containing the test compounds was removed and cell viability was evaluated using a 96-titer solution cell proliferation MTT assay in a microplate reader (UV absorption at $490 \mathrm{~nm}$ ).

5. Acknowledgment. A.M., A.A.G., and A.G. acknowledge support from the National Science Foundation (CHE-1464975) and the National Institutes of Health (SC1GM093830). Grant support to R.B. was provided by the National Institutes of Health (HL083187). G.A. 
acknowledges support from the Canadian Breast Cancer Foundation (Prairie/NWT). We thank Yaqiong Gong of Queens College of the City University of New York for assistance with the initial stages of the synthesis.

\section{References}

Abu-Yousef, I. A., Harpp, D. N., 1998. Sulfenyl Chloride Chemistry. New Precursors for Diatomic Sulfur Transfer. J. Org. Chem. 63, 8654-8660.

Abu-Yousef, I., 2006. The organic chemistry of diatomic sulfur. J Sulfur Chem., 27, 87-119.

Anwar, A., Burkholz, T., Scherer, C., Abbas, M., Lehr, C. M., Diederich, M., Jacob, C., 2008. Naturally occurring reactive sulfur species, their activity against Caco-2 cells, and possible modes of biochemical action. J. Sulfur Chem. 29, 251-268.

Asquith, C. R. M., Meli, M. L., Konstantinova, L.S., Laitinen, T., Poso, A., Rakitin, O. A., Hofmann-Lehmann, R., Allenspach, K., Hilton, S.T., 2015. Novel fused tetrathiocines as antivirals that target the nucleocapsid zinc finger containing protein of the feline immunodeficiency virus (FIV) as a model of HIV infection. Bioorg. Med. Chem. Lett. 25, 13521355.

Bentley, R., 2005. Role of sulfur chemistry in the chemical processes of biology. Chem. Soc. Rev. 34, 609-624.

Bittman, B., Li, Z., Samadder, P., Arthur, G., 2007. Anticancer activity of a ceramide analog containing a disulfide linkage. Cancer Lett. 251, 53-58.

Block, E., 2013. Fifty years of smelling sulfur. J. Sulfur Chem., 34, 158-207. 
Block, E., Dane, A. J., Thomas, S., Cody, R. B., 2010. Applications of direct analysis in real time mass spectrometry (DART-MS) in allium chemistry. 2-propenesulfenic and 2propenesulfinic acids, diallyl trisulfane S-oxide, and other reactive sulfur compounds from crushed garlic and other alliums. J. Agric. Food Chem. 58, 4617-4625 .

Brzostowska, E. M., Greer, A., 2003. The role of amine in the mechanism of pentathiepin (polysulfur) antitumor agents. J. Am. Chem. Soc. 125, 396-404.

Brzostowska, E. M., Greer, A., 2004. Polysulfane antitumor agents from o-benzyne. An oddeven alternation found in the stability of products $o-\mathrm{C}_{6} \mathrm{H}_{4} \mathrm{~S}_{\mathrm{x}}(\mathrm{x}=1-8)$. J. Org. Chem. 69, 54835485.

Brzostowska, E. M., Paulynice, M., Bentley, R., Greer, A., 2007. Planar chirality due to a polysulfur ring in natural pentathiepin cytotoxins. Implications of planar chirality for enantiospecific biosynthesis and toxicity. Chem. Res. Toxicol. 20, 1046-1052.

Castillo, A., Liebman, J. F., Greer, A., 2008. Quinones, monoradicals and diradicals from 3and 4-mercaptocatechol and 3,4-bismercaptocatechol: a computational study of a plausibly biomimetic reaction. J. Sulfur Chem. 29, 445-457.

Chatterji, T., Gates, K. S., 2003. Reaction of thiols with 7-methylbenzopentathiepin. Bioorg. Med. Chem. Lett. 13, 1349-1352.

Compagnone, R. S., Faulkner, D. J., Carte, B. K., Chan, G., Hemling, M. A., Hofmann, G. A., Mattern, M. R., 1994. Pentathiepins and trithianes from two Lissoclinum species and a Eudistoma sp.: inhibitors of protein kinase C. Tetrahedron 50, 12785-12792.

Czepukojc B., Leroch M., Salm F., Viswanathan U. M., Burkholz T., Hahn M., Jacob C., 2013. Antifungal activity of tetrasulfanes against Botrytis cinerea. Nat. Prod. Commun. 8, 15991603. 
Czepukojc, B., Viswanathan, U. M., Raza, A., Ali, S., Burkholz, T., Jacob, C., 2013. Tetrasulfanes as selective modulators of the ellular thiolstat. Phosphorus, Sulfur, Silicon Relat. Elem. 188, 446-453.

Davidson, B. S., Molinski, T. F.; Barrows, L. R., Ireland, C. M. 1991. Varacin: a novel benzopentathiepin from Lissoclinum vareau that is cytotoxic toward a human colon tumor. J. Am. Chem. Soc. 113, 4709-4710.

Delgado, A., Fabriàs, G., Bedia, C., Casas, J., Abad, J. L., 2012. Sphingolipid modulation: A strategy for cancer therapy. Anticancer Agents Med. Chem. 12. 285-302.

Delgado, A., Fabriàs, G., Casas, J., Abad, J. L., 2013. Natural products as platforms for the design of sphingolipid-related anticancer agents. Adv. Cancer Res. 117, 237-281.

Flowers, M., Fabriás, G., Delgado, A., Casas, J., Abad, J. L., Cabot, M. C., 2012. C6ceramide and targeted inhibition of acid ceramidase induce synergistic decreases in breast cancer cell growth. Breast Cancer Res. Treat. 133, 447-558.

Ford, P. W., Narbut, M. R. Belli, J., Davidson, B. S., 1994. Synthesis and structural properties of the benzopentathiepins varacin and lissoclinotoxin A. J. Org. Chem. 59, 5955-5960.

Gangoiti, P., Camacho, L., Arana, L., Ouro, A., Granado, M. H., Brizuela, L., Casas, J., Fabriás, G., Abad, J. L., Delgado, A., Gómez-Muñoz, A., 2010. Control of metabolism and signaling of simple bioactive sphingolipids: Implications in disease. Prog. Lipid Res. 49, 316334.

Greer, A., 2001. On the origin of cytotoxicity of the natural product varacin. A novel example of a pentathiepin reaction that provides evidence for a triatomic sulfur intermediate. J. Am. Chem. Soc. 123, 10379-10386. 
Jiang, C. S., Müller, W. E., Schröder, H. C., Guo, Y. W., 2012. Disulfide- and multisulfidecontaining metabolites from marine organisms. Chem. Rev. 112, 2179-2207

Konstantinova, L. S., Rakitin, O. A., Rees, C. W., 2004. Pentathiepins. Chem. Rev. 104, 2617-2630.

Konstantinova, L. S., Amelichev, S. A., Belyakov, P. A., Khakimov, D. V., Pivina, T. S., Lyssenko, K. A.; Rakitin, O. A., 2012. Formation of unsymmetrical 1,4-dithiins from fused 1,2,3,4,5-pentathiepins: synthesis, structural, and computational study. Tetrahedron 68, 590-597.

Konstantinova, L. S., Rakitin, O. A., 2014. Sulfur monochloride in organic synthesis. Russ. Chem. Rev. 83, 225-250

Koyioni, M., Manoli, M., Koutentis, P. A., 2014. Synthesis of fused 1,2,4-dithiazines and 1,2,3,5-trithiazepines. J. Org. Chem. 79, 9717-9727.

Lienard, B. M. R., Selevsek, N., Oldham, N. J., Schofield, C. J., 2007. Combined mass spectrometry and dynamic chemistry approach to identify metalloenzyme inhibitors. ChemMedChem 2, 175-179.

Litaudon, M., Guyot, M., 1991. Lissoclinotoxin A, an antibiotic 1,2,3-trithiane derivative from the tunicate Lissoclinum perforatum. Tetrahedron Lett. 32, 911-914.

Makarieva, T. N., Stonik, V. A., Dmitrenok, A. S., Grebnev, B. B., Iskov, V. V., Rebachyk, N. M., 1995. Varacin and three new marine antimicrobial polysulfides from the far-eastern ascidian Polycitor sp. J. Nat. Prod. 58, 254-258.

Mahendran, A., Vuong, A., Aebisher, D., Gong, Y., Bittman, R., Arthur, G., Kawamura, A., Greer, A., 2010. Synthesis, characterization, mechanism of decomposition, and antiproliferative activity of a class of PEGylated benzopolysulfanes structurally similar to the natural product varacin. J. Org. Chem. 75, 5549-5557. 
Merrill, A. H., 2011. Sphingolipid and glycosphingolipid metabolic pathways in the era of sphingolipidomics. Chem. Rev. 111, 6387-6422.

Mopper, K., Taylor, B. F., 1986. Biogeochemical cycling of sulfur. Organic Marine Geochemistry, Sohn, M. L., Ed., ACS, Washington, DC, USA, Chapter 19, pp. 324-339.

Morad, S. A., Levin, J. C., Shanmugavelandy, S. S., Kester, M., Fabrias, G., Bedia, C., Cabot, M. C., 2012. Ceramide--antiestrogen nanoliposomal combinations--novel impact of hormonal therapy in hormone-insensitive breast cancer. Mol. Cancer Ther. 11, 2352-2361.

Lee, A. H. F., Chen, J., Liu, D., Leung, T. Y. C., Chan, A. S. C., Li, T., 2002. Acid-promoted DNA-cleaving activities and total synthesis of varacin C. J. Am. Chem. Soc. 124, 13972-13973.

Lee, S. H., 2009. Disulfide and multisulfide antitumor agents and their modes of action. Arch. Pharm. Res. 32, 299-315.

Liu H., Pratasik S. B.; Nishikawa T., Shida, T., Tachibana, K., Fujiwara, T., Nagai H., Kobayashi, H., Namikoshi, M., 2004. Lissoclibadin 1, a novel trimeric sulfur bridged dopamine derivative, from the tropical ascidian Lissoclinum cf. Badium. Tetrahedron Lett. 45, 7015-7017.

Liu, H., Mishima, Y., Fujiwara, T., Nagai, H., Kitazawa, A., Mine Y., Kobayashi, H., Yao, X., Yamada J., Oda T., 2004. Namikoshi M. Isolation of araguspongine M, a new stereoisomer of an araguspongine/xestospongin alkaloid, and dopamine from the marine sponge neopetrosia exigua collected in Palau Hongwei. Marine Drugs 2, 154-163.

Molinski, T. F., 2004. Anti-infective agents. Curr. Med. Chem. 3, 197-220.

Münchberg, U., Anwar, A., Mecklenburg, S., Jacob, C., 2007. Polysulfides as biologically active ingredients of garlic. Org. Biomol. Chem. 5, 1505-1508.

Nielsen, R. W., Tachibana, C., Hansen, N. E., Winther, J. R., 2011. Trisulfides in proteins. Antioxid. Redox Signal. 15, 67-75. 
Ogawa, S., Yomoji, N., Chida, S., Sato, R., 1994. An effective and selective synthesis of sterically crowded benzotrithioles from benzodithiastannoles via benzotrithiole 2-oxides. Chem. Lett. 507-510.

Okuma, K., Munakata, K., Tsubota, T., Kanto, M., Nagahora, N., Shioji, K., Yokomori, Y., 2012. Synthesis and reaction of tricyclic tetrathiins and pentathiepins: novel formation of $\alpha$ disulfines. Tetrahedron 68, 6211-6217.

Passier, H. F., Bottcher, M. E., De Lange, G. J., 1999. Sulphur enrichment in organic matter of eastern Mediterranean sapropels: a study of sulphur isotope partitioning Aq. Geochem. 5, 99118.

Rys, A. Z., Abu-Yousef, I. A., Harpp, D. N., 2008. A powerful method to prepare sulfur-rich macrocycles. Tetrahedron Lett. 49, 6670-6673.

Sato, R., Akutsu, Y., Goto, T., Saito, M. 1987. Benzopentathiepin as sulfurization reagent. Novel synthesis of thiosulfonates from sulfinates. Chem. Lett. 16, 2161-2162.

Sato, R., Ohyama, T., Ogawa, S., 1995. Efficient synthesis and biological properties of new benzopentathiepins. Heterocycles 41, 893-896.

Sato, R., 2002. Heteroatom chemistry of cyclic benzopolychalcogenides: Synthesis and characterization. Heteroat. Chem. 13, 419-423.

Searle, P. A., Molinski, T. F., 1994. Five new alkaloids from the tropical ascidian, Lissoclinum sp. Lissoclinotoxin A is chiral. J. Org. Chem. 59, 6600-6605.

Schroll, A. L., Barany, G., 1986. Novel symmetrical and mixed carbamoyl and aminopolysulfanes by reactions of (alkoxydichloromethyl)polysulfanyl substrates with $\mathrm{N}$ methylaniline. J. Org. Chem. 51, 1866-1881. 
Startsev, A. N., Bulgakova, N. N., Ruzankin, S. Ph., Kruglyakova, O.V., Paukshtis, E. A., 2015. The reaction thermodynamics of hydrogen sulfide decomposition into hydrogen and diatomic sulfur. J. Sulfur Chem. 36, 234-239.

Steudel, R., 2002. The chemistry of organic polysulfanes $R-S_{n}-R(n>2)$. Chem. Rev. 102, 3905-3946.

Tachibana, K.; Kobayashi, H.; Mangindaane, R. E. P.; Namikoshi, M. Tetrahedron Lett. $2005,61,8611-8615$.

Tebbe, F. N., Wasserman, E., Peet, W. G., Vatvars, A., Hayman, A. C., 1982. Composition of elemental sulfur in solution: equilibrium of $S_{6}, S_{7}$, and $S_{8}$ at ambient temperatures. J. Am. Chem. Soc. 104, 4971-4972.

Tonika, C., Gates, K. S., 2003. Reaction of thiols with 7-methylbenzopentathiepin. Bioorg. Med. Chem. Lett. 13, 1349-1352.

Toste, F. D., Still, I. W., 1995. A new route to the synthesis of the naturally occurring benzopentathiepin varacin. J. Am. Chem. Soc. 117, 7261-7262.

Zubair, M., Ghosh, A. C., Schulzke, C., 2013. The unexpected and facile molybdenum mediated formation of tri- and tetracyclic pentathiepins from pyrazine-alkynes and sulfur. Chem. Commun. 49, 4343-4345.

Zysman-Colman, E., Harpp, D. N., 2007. Fascinating organosulfur functionalities: Polychalcogens as diatomic sulfur sources. Heteroat. Chem. 18, 449-459. 